\title{
Professional competencies to promote health in nursing and physical education undergraduate courses
}

\author{
Competências profissionais para promoção da saúde na formação em enfermagem e educação física \\ Competencias profesionales para promoción de la salud en la formación de enfermería y educación física
}

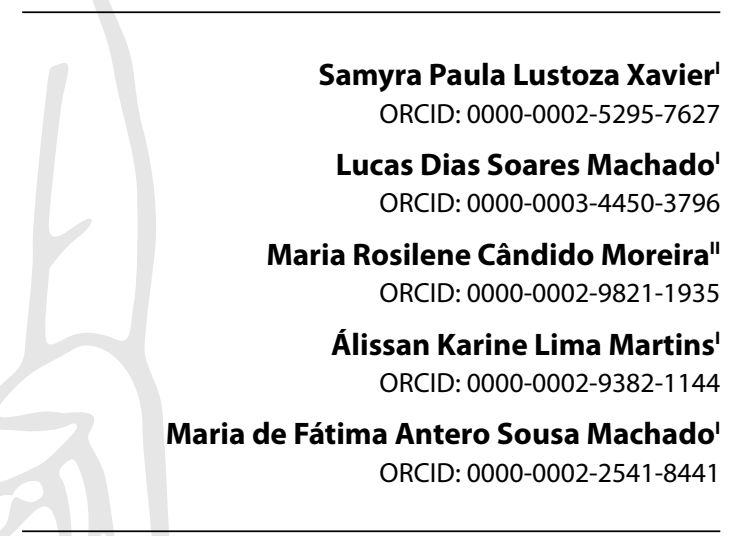

'Universidade Regional do Cariri. Crato, Ceará, Brazil. "Universidade Federal do Cariri. Barbalha, Ceará, Brazil.

How to cite this article:

Xavier SPL, Machado LDS, Moreira MRC, Martins AKL, Machado MFAS. Professional competencies to promote health in nursing and physical education undergraduate courses. Rev Bras Enferm. 2021;74(2):e20200617. https://doi.org/10.1590/0034-7167-2020-0617

\section{Corresponding author:}

Samyra Paula Lustoza Xavier

E-mail: samyralustoza@gmail.com

EDITOR IN CHIEF: Antonio José de Almeida Filho ASSOCIATE EDITOR: Hugo Fernandes

Submission: $07-15-2020$

Approval: 10-15-2020

\section{ABSTRACT}

Objectives: to recognize the competencies for health promotion and their magnitude of expression in undergraduate health education based on the analysis of the pedagogical projects of the courses and from the teaching perspective. Methods: research with a mixed approach, carried out at a public university. The data collected from the pedagogical projects of the Nursing and Physical Education courses and through interviews and application of a matrix of Competencies in Health Promotion with 31 professors of the referred courses were analyzed in the light of Competencies Health Promotion. Results: all competencies investigated were recognized in the curricula and reports of nursing professors, but the possibility of changes was not identified in the pedagogical project of Physical Education, although this competency was recognized as extremely important by the professors, with a mode of 4.5. Final Considerations: the training process in the courses studied has favored the development of skills for health promotion.

Descriptors: Health Promotion; Health Personnel; Professional Competency; Nursing; Physical Education and Training.

\section{RESUMO}

Objetivos: reconhecer as competências para promoção da saúde e sua magnitude de expressão no ensino de graduação em saúde, a partir dos projetos pedagógicos dos cursos e da perspectiva docente. Métodos: pesquisa com abordagem mista, realizada em uma universidade pública, cuja coleta deu-se a partir dos projetos pedagógicos dos cursos de Enfermagem e Educação Física; entrevista e aplicação de uma matriz de Competências em Promoção da Saúde com 31 docentes dos respectivos cursos, analisados à luz do Competencies Health Promotion. Resultados: todas as competências investigadas foram reconhecidas nos currículos e nos relatos dos docentes de Enfermagem, no entanto, na Educação Física, o domínio possibilidade de mudanças não foi identificado no projeto pedagógico, embora os docentes do curso a considerem uma competência de extrema importância, com moda de 4,5. Considerações Finais: o processo formativo nos cursos estudados tem favorecido o desenvolvimento de competências para promoção da saúde.

Descritores: Promoção da Saúde; Pessoal de Saúde; Competência Profissional; Enfermagem; Educação Física e Treinamento.

\section{RESUMEN}

Objetivos: reconocer las competencias para promoción de salud y su magnitud de expresión en la enseñanza de carreras de salud en base al análisis de proyectos pedagógicos de los cursos y la perspectiva docente. Métodos: investigación de abordaje mixto realizada en una universidad pública. Datos recolectados de proyectos pedagógicos de las carreras de Enfermería y Educación Física, y mediante entrevistas y aplicación de una matriz de Competencias en Promoción de Salud con 31 docentes de dichos cursos; analizados utilizando el Competencies Health Promotion. Resultados: todas las competencias investigadas fueron reconocidas en los programas y las narraciones de los docentes de Enfermería. El dominio "posibilidad de cambios" no fue identificado en el proyecto pedagógico de Educación Física, aunque la competencia fue reconocida como extremadamente importante por los docentes, con moda de 4,5. Consideraciones Finales: el proceso formativo en las carreras estudiadas ha favorecido el desarrollo de competencias para promoción de la salud.

Descriptores: Promoción de la Salud; Personal de Salud; Competencia Profesional; Enfermería; Educación y Entrenamiento Físico. 


\section{INTRODUCTION}

The incorporation of health promotion as a public health paradigm triggered discussions about the adequacy of professional training to work in this field. In Brazil, these debates are converging with the continuous attempt to ensure that the principles of universality, equity and social participation of the Sistema Único de Saúde (SUS) (Unified Health System) are effectively addressed in health care.

Related to this panorama, the National Curriculum (NC), the guiding instrument for professional health education, defines the fundamentals and principles for academic training. The objective is to obtain a profile of graduates with competencies to act in health care through the development of health prevention actions, health promotion, protection and rehabilitation ${ }^{(1)}$.

Some professional skills, here recognized as a combination of abilities, attitudes and knowledge necessary for performance in the health field $\mathrm{d}^{(2)}$, pointed out by the $\mathrm{NC}$ are health attention, decision making, communication, leadership, administration and management, and continuing education ${ }^{(3)}$. However, these competencies are very broad, not specifying what actions are necessary to achieve them to establish a professional standard for acting in health promotion.

Considering the complexity and the existing gaps in training for the development of skills in the health scenario, European researchers developed the Developing Competencies and Professional Standards for Health Promotion Capacity Building also known as Competencies Health Promotion Project (CompHP) ${ }^{(4-6)}$. This document contemplates a minimum set of knowledge, skills and attitudes that constitute the common and essential basis for all health promotion functions, providing subsidies to guide the training of the health workforce ${ }^{(6)}$.

It should be noted that the CompHP, although established based on the reality of public health in Europe, points out possibilities for reorienting professional performance in the field of health promotion, to overcome the predominantly curative and disarticulated approach to health practices. In this sense, it is in line with the assumptions of policies that induce health education in the Ministries of Health and Education ${ }^{(7-8)}$ within the scope of SUS.

In this light, the scientific literature emphasizes the need to develop research that indicates the necessary adaptations and specificities for the reorientation of health education ${ }^{(5,9-12)}$. Understanding how the skills for health promotion are manifested in professional training is unique, as well as recognizing how they are included in the pedagogical projects of the courses and mobilized by their professors. These reflections were constituted as central issues in the present study.

\section{OBJECTIVES}

To recognize the competencies for health promotion and their magnitude of expression in undergraduate health education based on the analysis of the pedagogical projects of the courses and from the teaching perspective.

\section{METHODS}

\section{Ethical aspects}

This study is part of a multicenter study, entitled "Studies on Health Promotion in Educational and Work Environments", approved by the Research Ethics Committee. All prerogatives of Resolution n. 466/12 on ethical care in research involving human beings were followed ${ }^{(13)}$.

\section{Theoretical Framework}

The CompHP was adopted as a theoretical framework for conducting the study. This covers a set of 46 competencies necessary to create effective actions in health promotion, organized in nine dimensions, namely the possibility of changes, health advocacy, partnership, communication, leadership, diagnosis, planning, implementation and evaluation and research ${ }^{(6)}$.

\section{Type of study}

Descriptive, documentary and field research, of a study case type, with a mixed approach ${ }^{(14)}$. The sequential exploratory WHICH $\rightarrow$ quan execution was chosen, in which quantitative data complement the qualitative data collected and initially analyzed ${ }^{(15)}$. This way, the communication of results followed the guidelines of the Consolidated Criteria for Reporting Qualitative Research (COREQ) ${ }^{(16)}$.

\section{Study setting}

It was defined as a research field a public university located in the southern region of the state of Ceará, due to its strategic role for the region in professional training and knowledge production. It offers 16 undergraduate courses, three of them in the health area: Biological Sciences, Nursing and Physical Education. The last two were selected to compose this study, due to the nature of the training of these professionals, which requires students to have skills to work in the field of public/collective health.

The undergraduate nursing course, established in 1998, is a bachelor's degree and is divided into ten semesters, making a total workload of 4,485 hours. The Physical Education degree course, established in 2013, has a workload of 3,620 hours divided into eight semesters. Both courses foster professional competencies according to their respective $\mathrm{NC}$, and the training takes place based on the teaching-research-extension tripod, with semester entry.

\section{Data source}

To achieve the object of study, three data sources were chosen: the documentary data, subsidized by reading the Pedagogical Projects (PP) of the Nursing and Physical Education courses, were materialized as instruments that guide their practices, being, therefore, essential to consider them.

The speeches of 31 professors from the referred university were also analyzed, given their performance in the training of health professionals. For that, the following inclusion criteria were chosen: to be a professor in Nursing and Physical Education courses and to exercise the teaching role for at least one year. Professors absent from their activities for any reason did not participate.

The Health Promotion Competency Matrix (CompEPS) ${ }^{(17)}$ was also used. Based on the CompHP framework, CompEPS was validated and deals with the essential skills to be developed by health-promoting professionals in the Brazilian context. 


\section{Data collection and organization}

The operationalization of data collection took place from July to October 2018.

After the authorization and availability of PP by the secretariats of the respective courses, the reading and data collection stage began, guided by an instrument of our elaboration, contemplating health promotion skills. In this process, attention was given to the objectives, the theoretical-methodological framework, the curricular matrix, and the programmatic content, recognizing the approximations and distances with the adopted theoretical framework.

The interviews with the 31 professors, 22 professors from the Nursing course and nine from the Physical Education course, were carried out at the university itself, in a private location, with only the presence of a researcher and the interviewee. The interview was guided by open questions that contemplated the skills considered essential by the subjects to carry out health promotion actions and curricular components that favor their development. The speeches were recorded in digital media, lasted an average of 30 minutes, and were ended when the theoretical saturation in the collected content was recognized.

To ensure methodological rigor during the interview, at the end of the statements, the information was reproduced by the researcher so that the professors could refute, add information not yet said or confirm the idea expressed. In the speech fragments presented in this study, the participants were identified by an alphanumeric system, following the sequence of data collection (P01, P02...), to preserve their confidentiality and identity.

After the interviews, the CompEPS Matrix was applied to the participants, on the five-point Likert scale, suggesting the level of relevance attributed by the professor to the essential skills in health promotion in the training process in which he/she was inserted.

This threesome of information aimed to ensure a deeper understanding of the phenomenon under study.

\section{Data analysis}

Thematic Analysis was used, guided by the theoretical contribution of the CompHP for organization and documentary analysis and of the contents of the interviews with the professors, from the perspective of analytical categories, treating each dimension as a category ${ }^{(18)}$.

The CompEPS Matrix data were processed using the SPSS version 23.0 for Windows ${ }^{\circledR}$ program and subsequently subjected to descriptive statistical treatment, with the calculation of mode and interquartile range. A calculation was performed to establish the mean mode of each competency designated by the dimension to represent the Magnitude of Global Expression (MGE), portraying the importance attributed by the professors to the analyzed dimension.

\section{RESULTS}

As for the characterization of the 31 professors participating, they were mostly female (21), with an average age of 38 years, ranging from 25 the minimum age and 62 the maximum. Regarding teaching time, a minimum period of one year and a maximum period of 25 years were obtained, making an average of 10 years and 7 months in teaching.

Regarding the profile of the subjects they teach at graduation, most professors (20) are based in theoretical-practical subjects, 12 teach theoretical subjects and 10 practical subjects, which take place within the scope of public health services. It should be noted that some professors teach more than one subject.

Considering the competency dimensions of CompHP, this section brings the main findings on health promotion competency dimensions expressed in the training of Nursing and Physical Education, identified from the analysis of the PP, the interviews and the MGE, presented in Chart 1.

Chart 1 - Identification of health promotion competency dimensions, Crato, Ceará, Brazil

\section{POSSIBILITY OF CHANGES}

Professional action to enable individuals, groups, communities or organizations to build capability for response in health promotion, and thus improve and reduce health inequities ${ }^{(2)}$

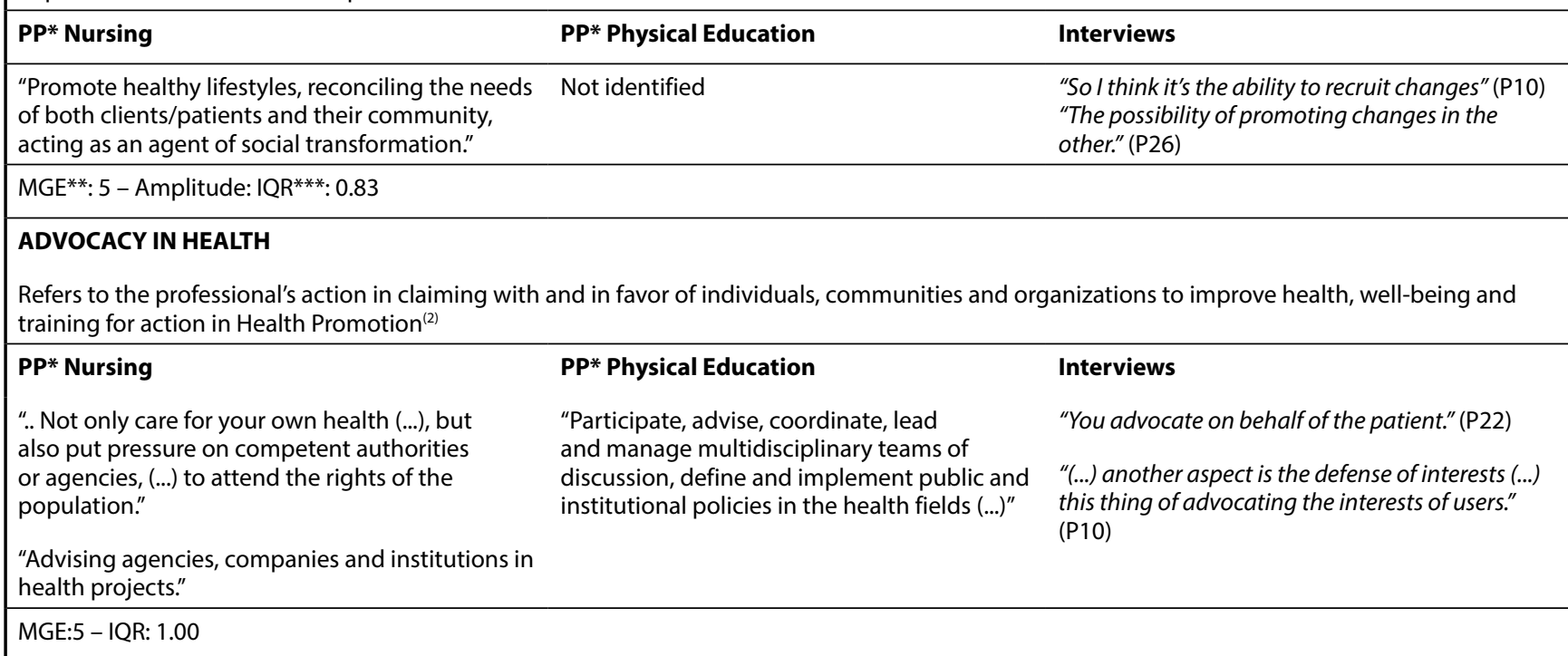




\section{PARTNERSHIP}

It consists of working in collaboration with areas of knowledge/disciplines, sectors and partners to increase the impact and sustainability of Health Promotion actions ${ }^{(2)}$

\section{PP* Nursing \\ PP* Physical Education}

"Each professional must ensure that their practice is carried out in an integrated and continuous manner with the other instances of the health system."

$M G E^{* *}: 4.75-I Q R^{* * *}: 1.00$
"Participate, advise, coordinate, lead and manage multidisciplinary teams of discussion, define and implement public and institutional policies in the health fields (...)"

\section{Interviews}

"Promote partnerships with the responsible agency to be also helping in that health promotion process, partnerships." (P02)

\section{COMMUNICATION}

It manifests itself when communicating health promotion actions effectively, using appropriate techniques and technologies for different audiences $^{(2)}$

\section{PP* Nursing}

"Use new technologies, both for information and communication as high tech to care."

"Communication involves verbal, non-verbal forms and writing and reading skills; mastering at least one foreign language and technologies of information and communication."

\section{PP* Physical Education}

"Make use of information and communication technology to expand and diversify the ways of interacting and sharing the sources of production and diffusion of

knowledge and technologies."

"Adequacy and objectivity in the forms of written, verbal and non-verbal communication."

\section{Interviews}

"I believe you have to know (...) the ability I bring more from communication." (P17)

"Knowing how to deal with this aspect of communication, I think communication skills are extremely important (...) and then communicating involves knowing how to listen and knowing how to speak." (P09).

$M \mathrm{ME}^{* *}: 5.0-\mathrm{IQR}^{* * *}: 0.66$

\section{LEADERSHIP}

Contribute to the development of a shared view and strategic directions for action in health promotion ${ }^{(2)}$

\section{PP* Nursing PP* Physical Education}

"The work of professionals must be based on the ability to make decisions..."

“Demonstrate leadership with students and the school community."

"The professionals must be able to take initiatives, (...) leaders in the health team."
"Solve real problems of professional practice and the dynamics of educational institutions, ensuring the learning and development of students and the school community."

$\mathrm{MGE}^{* *}: 4.66-\mathrm{IQR}^{* * *}: 1.00$

\section{DIAGNOSIS}

It refers to the action of diagnosing the needs and potential of a partnership with social actors/partners, in the context of political, economic, social, cultural, environmental, behavioral and biological determinants that promote or compromise health ${ }^{(2)}$

\section{PP* Nursing}

"Understand health policy in the context of social policies, recognizing the epidemiological profiles of populations."

"Identify the individual and collective health needs of the population, their conditions and determinants."

\section{PP* Physical Education}

"Critically consider the characteristics, interests and needs of students and the school community."

"Understand the socio-cultural, political, economic and environmental implications (...) to act in a critical-overcoming way."

\section{Interviews}

"For health promotion leadership skills come in." (P05)

"Like, he needs to have that leadership spirit, know how to move, coordinate people, actions." (P06)

$M G E^{* *}: 5.0-I Q R^{* * *}: 0.66$

\section{PLANNING}

Comprises actions to mobilize individuals to develop health promotion goals and objectives that can be measured, based on the diagnosis of needs and potential in partnership with social actors/partners ${ }^{(2)}$

\section{PP* Nursing}

"Responding to regional health specificities through strategically planned interventions."

"Coordinate teamwork, select, prioritize and analyze problems to build intervention plans."

\section{PP* Physical Education}

"Planning, implementation and evaluation of professional intervention programs."

\section{Interviews}

"So, I think it's the ability to identify the problem, to technically know the problem in question." (P01)

"Develop in them a critical-reflective thinking that they can identify a problem, not only see a reality and see an apparent problem but see what is beyond that problem." (P14)

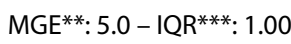




\section{IMPLEMENTATION}

It is based on the implementation of effective, efficient, culturally sensitive and ethical health promotion actions, in partnership with social actors/ partners $^{(2)}$

\section{PP* Nursing \\ PP* Physical Education}

"Plan and implement an education and health promotion program, considering the specificities of different social groups and the different processes of life, health, work and illness."
"Analyze reflexively to intervene ethically in your daily professional situations."

"Planning, implementation and evaluation of professional intervention programs."

$M \mathrm{ME}^{* *}: 5.0-1 \mathrm{QR} \mathrm{R}^{* * *}: 0.83$

\section{EVALUATION AND RESEARCH}

Use of appropriate assessment and research methods, in partnership with social actors/partners, to determine the scope, impact and effectiveness of health promotion actions ${ }^{(2)}$

\section{PP* Nursing}

"Evaluate, systematize and decide the most appropriate conduct, based on scientific evidence."

"Develop, participate and apply research and/or other forms of knowledge production that aim to qualify professional practice."

\section{PP* Physical Education}

"Knowing, mastering, producing, selecting and evaluating the effects of applying different techniques, instruments, equipment, procedures and methodologies."

"Take over a critical-reflexive attitude about the research results for the adequacy and improvement of interventions."

\section{Interviews}

"Plan actions, implement and evaluate." (P12)

"Perform interventions, implementation and evaluation." (P13)

$M G E^{* *}: 5.0-1 Q R^{* * *}: 0.60$

Note: *PP-Pedagogical Project; **MGE-Magnitude of Global Expression; ${ }^{* * *}$ IQR-Interquartile Range

In the PP of the Physical Education course, except for the possibility of changes, the presence of the dimensions of competencies in health promotion was recognized in the documents guiding the training of the analyzed courses and in the speeches of the professors of these courses.

Besides the areas of competency, it was possible to identify that the PP of the courses studied are also in line with the ethical values and basic knowledge covered in CompHP. This is evident when they signal the importance of considering the political, economic, social, cultural, environmental, behavioral and biological determinants of individuals for the promotion of health and well-being, when they recognize the beliefs and preferences expressed by individuals and as they foster the need for continuous reflection on behavior and professional practice to identify improvements in their performance.

The MGE assigned to each dimension reveals that professors recognize all dimensions of competency in health promotion as extremely important to health training (mode $\geq 4.5$ ).

\section{DISCUSSION}

Even though all other competency dimensions have been found, the failure to identify the possibility of changes in the Physical Education PP provokes reflections on the importance of the official document that rules the course to highlight it, so that it guides the professor and sensitizes him/her to provide the opportunity for the development of this competency during the student's training. However, the expressiveness in the professor's speech and the magnitude of importance given by them to this attribute allows saying that the professors are sensitive to this need, evidencing an advance towards the competencies for health promotion.
The possibility of changes dimension in undergraduate nursing shows the development of skills based on critical reflection to act promoting modifications and improvements in different social contexts, since it provides a theoretical and practical basis for the development of health actions. It is worth mentioning that these actions are guided by the educational and health principles from relevant policies and documents ${ }^{(19)}$.

The possibility of changes begins with the redirection of training processes, through political and institutional advances in health promotion, with the implementation of initiatives in the field of public and collective health and (re)formulation of public policies that induce professional training based on skills $s^{(2-19)}$. It is observed in this, as in other studies ${ }^{(20-21)}$, that health training, especially in the context of Nursing, is in the process of reorientation and has stimulated the development and adoption of its professional role as social actors and agents of social transformation.

Aware that the changes to improve the health scenario start from democratization and promotion of access to services and goods to its users, the health advocacy dimension also presents itself as an instrument for the defense of the universal right to health, promptly articulating itself the possibility of changes ${ }^{(22)}$.

Promoting health requires much broader actions than simply individual ones. It involves a set of aspects related to social determinants and conditions that interfere in the health of the individual and the community ${ }^{(23)}$. It is not just a matter of preventing illnesses, treating a disease, or educating in health, but it comprises the development of new models of health care that support actions aimed at the health of the community. In this context, it is reaffirmed, therefore, the relevance of health promotion actions, through the involvement of citizens and, together with them, in the guarantee and effectiveness of their health rights. 
The idea of claiming with and in favor of the population shows participation and/or social control, as stated in the principles and guidelines of the SUS and the Política Nacional de Atenção Básica - PNAB (National Primary Care Policy) ${ }^{(24-25)}$. This approach to public health policies, their foundations and precepts, potentiates the development of health advocacy through the teachingservice-community integration, according to the proposals of the analyzed training processes.

The proposal to advocate in health, within the scope of integration with health services and with the collectivities to which they belong, is based on the principle that the mobilization of different sectors and actors is necessary for the effectiveness of comprehensiveness and universality in health.In this sense, the partnership, which is also one of the guidelines of the Política Nacional de Promoção da Saúde - PNPS (National Health Promotion Policy), emerges as an essential competency, whose main purpose is to encourage intersectoral actions that enable the comprehensive development of health promotion actions ${ }^{(26)}$.

In this context, urge the challenge for training processes to advance in the establishment of intra and intersectoral combinations, under the logic of incorporation and collaboration of the work of several other sectors (educational, cultural, economic, political, among others) to health. Also emerges the challenge of implementing multi and interprofessional work to meet the most emerging needs of the individual and collective population.

Establishing partnerships focused on health promotion also presupposes the exchange of knowledge between the different training processes and different areas of knowledge. From this perspective, these exchanges must be effective and significant in knowledge and practices, driven by dialogue and the valorization of different knowledge ${ }^{(27)}$ so that, together, they work towards a common goal(28).

Considering the complexity of working in intersectoral and interdisciplinary networks that are necessary for the health field, the relationships of partnerships are consolidated based on good communication practices between the various actors that are part of this context, including users and professionals.

Communication manifested itself as a dimension of competencies to be developed during professional training, encompassing verbal and non-verbal aspects, and enabling the implementation and use of information and communication technologies as a strategy to assist this process. Such aspects are consistent with the NC of the courses under study.

Vocational training should enable the development of permanent general skills and abilities of communication and education that include the mastery of information and communication technologies ${ }^{(3)}$.

Although communication is recognized as essential for professional training, some inconsistent aspects between the desired and the offered were identified in the analyzed PP, such as the acknowledgment of the importance of mastering a foreign language, however without offering this type of subject in the curriculum. Another inconsistency was the absence of a discipline of Brazilian Sign Language, not considering the communicative process with hearing impaired, for example, which goes against the principles of integrality and universality of health care.
The meaning of the word communicate refers to "put in common", for this purpose, the act of communicating in the health field calls for the appreciation of the understanding of life contexts and meanings of illness from the user's perspective. Thus, the professional must be open to welcome the other and develop their communication skills ${ }^{(29)}$.

In this light, the relevance of establishing good communication relationships between professors-students and/or professionalpatient/user is highlighted, since, when established through a therapeutic relationship, they are favorable for decision making in SUS and development of health promotion actions, based on dialogue, qualified listening, as well as non-verbal manifestations. The main objective must be based on the transmission of information in an effective way, making the user active and autonomous in health decisions that favor self-care ${ }^{(29)}$.

In general, health care actions are based on exchanges introduced during the communication process, which should favor a horizontal relationship between the professional and the service user. This makes it easier to reach the goals set for improving the population's quality of life and health.

Characterized as the ability to coordinate an individual or group to influence it positively, the leadership competency was also highlighted in the studied reality, manifesting itself in the encouragement to exercise decision-making, proactivity, the leadership of the work in team and problem solving, evidenced in the statements and documents analyzed ${ }^{(30)}$.

Leadership enables professionals to develop their role with a focus on transforming ideas, intentions, goals and, consequently, results, balancing the work environment, actively participating in the planning processes and encouraging the leadership skills of other professionals ${ }^{(31)}$. Thus, it is possible that, together with the users of the health service, they can transform the reality in which they are inserted, thus, in line with the NC.

In this sense, the success of the professional who exercises leadership occurs through observation and attention to trends, perceptions and needs of users of the health service. It also depends on a permanent evaluation of the implemented actions, which can be cases of success or failure, but which make the professional more and more resistant to the challenges they are faced with ${ }^{(32)}$.

Concerning the dimensions of diagnosis, planning, implementation, evaluation, and research there is an interconnection between them, manifesting themselves as complementary steps in a sequential and cyclic process ${ }^{(33)}$. Thus, one cannot advance successfully in one of the dimensions without the full growth of another.

The diagnostic dimension is foreseen in the training of undergraduate students in both courses. Some of the main aspects related to it are the need to analyze the problems of society, recognize the epidemiological profiles of populations, consider the interests, and needs of students, among others. The NC describe as desirable that the professional has the ability and attitude to diagnose people's interests, expectations and needs, so that they can solve health problems, encompassing this dimension ${ }^{(3,30)}$.

It is important to note that health diagnosis is not only about health problems and needs, but it is also possible to diagnose potentialities. These can be social actors or other services and devices that favor a better relationship between service-community and help to promote a better quality of life and health. 
Thus, when the professional has the diagnostic ability, he/she can develop a more critical view and, based on the identification of situations that enhance or hinder the reach of health, he/she adds planning to the work. It is worth mentioning that planning is the relevant dimension for the construction of proposals that solve the demands found in a good diagnosis.

The planning guides health work, as it allows professionals to guide their actions based on the goals and objectives they intend to achieve. Therefore, an expanded situational analysis is necessary, to identify the epidemiological, territorial profile, raise own resources, make a subjective analysis and map the relationships between service and users ${ }^{(34)}$.

This aspect allows us to highlight the importance of planning as a necessary competency for carrying out health actions. However, it is worth noting that, just as it is necessary to diagnose to plan, it is essential that this planning precedes the action, that is, the implementation of planned care.

The implementation dimension, as indicated in the PP, is based on the development of actions for health promotion and education, which are presented as facilitating strategies in the processes of changes in lifestyles, work and, consequently, in the health-disease process, through critical and ethical analysis of reality, considering the particularities and needs of those involved. It is the effectiveness of health promotion actions in acts, in the territories, with individuals, their collectivities and their realities.

Thus, the implementation of health promotion actions must be incorporated into the realities of health services and aligned with the desired care model, especially in the routine of primary care services. This reaffirms the need to integrate the academy and health services in professional training.

According to the data presented, the competency of evaluation and research is based on the judgment of the actions taken, the results of which will serve as a basis for decision making. The term evaluation refers to an understanding of something in which a judgment needs to be made - an intervention or any other aspect. For this, it is necessary to make a careful analysis of what was planned, executed, implemented and achieved.

In this sense, health assessment aims to support decisionmaking processes, subsidizing the reorientation of actions and services, and measuring the impact of the actions implemented on the population's health and well-being, materializing as a possibility and a necessity ${ }^{(35)}$. From this perspective, health assessment should be understood as formative, capable of promoting improvements, support and encouragement for positive transformations in the activities and actions implemented, and not as punitive, as has sometimes been understood ${ }^{(36)}$.

This evaluation process must be intrinsically linked to research, anchoring itself in evidence-based practice and strengthening it. Therefore, there is an urgent need to reduce the gap between conducting research and health services, in a real and effective process of teaching-service-community integration that ensures the development of skills not only by students and professors involved in the process, but also by professionals and the community as part of this relationship web.

Such perspective starts from the need to face the consolidation of the concept that research is an exclusive or priority job of the university, ensuring the involvement of professionals in the construction of scientific knowledge in health ${ }^{(37)}$.

\section{Study Limitation}

It is recognized as a limitation the failure to capture the object under practical aspects, along with formative moments such as classes and internships, as well as under the student perspective, these being possibilities for the development of future work.

\section{Contributions to the area}

Propose reflections on the necessary updating of undergraduate health courses to provide professional training concerning the development of skills for health promotion. It is also expected that this study will contribute, through a local reality, to foster evaluation practices, through the union of current trends, social and ideological changes, and to promote changes that (re)guide the training processes in health.

\section{FINAL CONSIDERATIONS}

The dimensions of competencies for health promotion are present in the training processes of Nursing and Physical Education courses, which denotes training aligned with health promotion and relevant to professional performance in SUS. This indicator represents an advance in the organization of pedagogical practices, since it is in line with national and international debates essential to the implementation of health practices, overcoming challenges and contributing to the training of professionals capable of acting with quality.

However, it is recognized that only the contemplation of these areas of competency in the formative documents and the speeches of the professors involved in the formative processes does not ensure their full development. These dimensions must transcend the theoretical-normative aspect of training and reach the spaces for debate and formative practice. It is also supported the need to develop the completeness of the presented dimensions, since there is a logical and dependent relationship between them, important to the work of the health promoter.

\section{FUNDING}

The present work was carried out with the support of the Fundação Cearense de Apoio ao Desenvolvimento Científico e Tecnológico (FUNCAP) (Ceará Foundation for Support to Scientific and Technological Development).

\section{REFERENCES}

1. Carvalho VL, Oliveira ALC, Alves IKS, Silva RL, Silva CB. Competências para promoção da saúde em formandos dos cursos da área da saúde. Rev Enferm UFPE. 2017;11(8):3269-78. https://doi.org/10.5205/reuol.11135-99435-1-ED.1108sup201711 
2. Dempsey C, Barry M, Battel-Kirk B. The CompHP core competencies framework for health promotion handbook: workpackage 4 [Internet]. Galway: Executive Agency for Health Promotion and Consumers: National University of Ireland. 2011 [cited 2017 Jul 10]. 1-27. Available from: http://www. szu.cz/uploads/documents/czzp/nerovnosti/2011/5._CompHP_Core_Competencies_Framework_for_Health_Promotion_Handbook_revised.pdf

3. Ministério da Educação (BR). Resolução n. 3, de 7 de novembro de 2001. Institui diretrizes curriculares nacionais do curso de graduação em enfermagem [Internet]. Diário Oficial da União, Brasília (DF); 9 de novembro de 2001 [cited 2018 Feb 27]. Avaliable at: http://portal.mec.gov. br/dmdocuments/ces1133.pdf

4. Pinheiro DGM, Scabar TG, Maeda ST, Fracolli LA, Pelicioni MCF, Chiesa AM. Competências em promoção da saúde: desafios da formação. Saúde Soc. 2015;24(1):180-8. https://doi.org/ 10.1590/S0104-12902015000100014

5. Xavier SPL, Pereira AP, Moreira MRC, Martins AKL, Ferreira HS, Machado MFAS. Competencies in promoting health in the light of the project Competencies Health Promotion (CompHP): an integrative review. Cienc Cuid Saude. 2019;18(1):e43421. https://doi.org/10.4025/ cienccuidsaude.v18i1.43421

6. Battel-kirk B, Barry MM. Developing competency-based accreditation for health promotion in Europe. Rev Med [Internet]. 2013[cited 2018 Mar 18];92(2):87-96. Available from: https://www.revistas.usp.br/revistadc/article/viewFile/79564/83582

7. Ministério da Saúde (BR). Ministério da Educação. Programa Nacional de Reorientação da Formação Profissional em Saúde - Pró-Saúde: objetivos, implementação e desenvolvimento potencial [Internet]. Brasília (DF); 2007[cited 2019 Aug 04]. Available: http://bvsms.saude.gov. br/bvs/publicacoes/07_0323_M.pdf

8. Ministério da Saúde (BR). Portaria Interministerial no 1.802 de 29 de Agosto de 2008. Institui o Programa de Educação pelo Trabalho para a Saúde - PET - Saúde [Internet]. Brasília (DF); 2008 [cited 2019 Aug 04]. Available: http://bvsms.saude.gov.br/bvs/saudelegis/gm/2008/ pri1802_26_08_2008.html

9. Lima AWS, Alves FAP, Linhares FMP, Costa MV, Coriolano-Marinus MWL, Lima LS. Percepção e manifestação de competências colaborativas em discentes da graduação em saúde. Rev Latino-Am Enfermagem. 2020;28:e3240. https://doi.org/10.1590/1518-8345.3227.3240

10. Tavares MFL, Rocha RM, Bittar CML, Petersen CB, Andrade MA. Promoção da saúde no ensino profissional: desafios na saúde e a necessidade de alcançar outros setores. Ciênc Saúde Coletiva. 2016;21(6):1799-808. https://doi.org/10.1590/1413-81232015216.07622016

11. Netto L, Silva KL. Reflective practice and the development of competencies for health promotion in nurses' training. Rev Esc Enferm USP. 2018;52:e03383. https://doi.org/10.1590/S1980-220X2017034303383

12. Machado MFAS, Machado LDS, Xavier SPL, Lima LA, Moreira MRC, Ferreira HS. Competências em promoção da saúde: o domínio parceria na residência multiprofissional em saúde. Rev Bras Promoç Saúde. 2018;31(4):1-7. https://doi.org/10.5020/18061230.2018.8761

13. Ministério da Saúde (BR). Conselho Nacional de Saúde. Resolução n 466, de 12 de dezembro de 2012. Aprova as diretrizes e normas regulamentadoras de pesquisas envolvendo seres humanos [Internet]. 2012[cited 2019 Aug 04]. Available: https://bvsms.saude.gov.br/bvs/ saudelegis/cns/2013/res0466_12_12_2012.html

14. Creswell JW. Investigação Qualitativa \& Projeto de Pesquisa. 3a Ed. Porto Alegre, Penso: 2014.

15. Santos JLG, Erdmann AL, Meirelles BHS, Lanzoni GMM, Cunha VP, Ross R. Integração entre dados quantitativos e qualitativos em uma pesquisa de métodos mistos. Texto Contexto Enferm. 2017;26(3):e1590016. https://doi.org/10.1590/0104-07072017001590016

16. Tong A, Sainsbury P, Craig J. Critérios consolidados para relatar pesquisa qualitativa (COREQ): uma lista de verificação de 32 itens para entrevistas e grupos focais. Cuid Saúde Int J Qual. 2007;19 (6):349-57. https://doi.org/10.1093/intqhc/mzm042

17. Moreira MRC, Machado MFAS. Matrix of essential competencies in health promotion: a proposal for the Brazilian context. Health Promot Int. 2019;1(13):096. https://doi.org/10.1093/heapro/daz096

18. Minayo MCS. O desafio do conhecimento: pesquisa qualitativa em saúde. 12ªed. São Paulo: Hucitec; 2010.

19. Tusset D, Nogueira JAD, Rocha DG, Rezende R. Análise das competências em promoção da saúde a partir do marco legal e dos discursos dos profissionais que implementam o Programa Saúde na Escola no Distrito Federal. Tempus Actas Saúde Colet [Internet]. 2015[cited 2019 May 5];9(1):189-204. https://doi.org/10.18569/tempus.v9i1.1701

20. Souza EC, Castro Jr AR, Cavalcante ASP, Torres RAM, Silva MRF. Projeto Vivências e Estágios na Realidade do Sistema Único de Saúde: linha de fuga na formação em saúde para uma atuação na saúde coletiva. Saúde Debate, 2019;43(122):897-905. https://doi.org/10.1590/0103-1104201912219

21. Silva ANC, Moreira DP, Freitas CMA, Teixeira AKS, Pinheiro ARM. Estágio extracurricular de enfermagem: estratégia para a formação profissional. Enferm Foco 2019;10(4):129-35. https://doi.org/10.21675/2357-707X.2019.v10.n4.1880

22. Brehmer LCF, Ramos FRS. Experiências do programa de reorientação da formação profissional na enfermagem: avanços e desafios. Texto Contexto Enferm. 2017;26(2):e3100015. https://doi.org/10.1590/0104-07072017003100015

23. Carrapato P, Correia P, Garcia B. Determinante da saúde no Brasil: a procura da equidade na saúde. Saúde Soc. 2017;26(3):676-89. https://doi. org/10.1590/S0104-12902017170304

24. Presidência da República (BR). Lei nº. 8080, de 19 de setembro de 1990. Lei Orgânica da Saúde [Internet]. 1990[cited 2019 May 5]. Available from: http://www.planalto.gov.br/ccivil_03/leis//8080.htm

25. Presidência da República (BR). Lei no 13.415 de 16 de fevereiro de 2017. Altera as Leis nos 9.394, de 20 de dezembro de 1996, que estabelece as diretrizes e bases da educação nacional [Internet]. 2017[cited 2018 Apr 02]. Available from: http://www.planalto.gov.br/Ccivil_03/_ Ato2015-2018/2017/Lei/L13415.htm\#art7 
26. Ministério da Saúde (BR). Portaria № 2.446/GM de 11 de novembro de 2014. Redefine a Política Nacional de Promoção da Saúde (PNPS). Brasília, DF; 2014.

27. Germani ACCG, Aith F. Advocacia em promoção da saúde: conceitos, fundamentos e estratégias para a defesa da equidade em saúde. Rev Dir Sanit. 2013;14(1):34-59. https://doi.org/10.11606/issn.2316-9044.v14i1p34-59

28. Casanova IA, Batista NA, Ruiz-Moren L. Formação para o trabalho em equipe na residência multiprofissional em saúde. Arq Bras Ciênc Saúde [Internet]. 2015 [cited 2019 May 5];40(3):229-33. Available from: https://www.portalnepas.org.br/abcshs/article/view/800/695

29. Monteiro JK, Dalenogare FS, Santos GO, Rodrigues MLA, Quadros MO, Bratkowski PS, et al. Comunicação em saúde: relato de experiência com trabalhadores da saúde. Pesqui Prát Psicossoc [Internet], 2018 [cited 2018 Sep 5];13(2):e1124. Available from: http://www.seer.ufsj.edu. br/index.php/revista_ppp/article/view/2969/1909

30. Amestoy SC, Oliveira AFL, Thofehrn MB, Trindade LL, Santos BP, Bao ACP. Contribuições freirianas para entender o exercício da liderança dialógica dos enfermeiros no ambiente hospitalar. Rev Gaúcha Enferm. 2017;38(1):e64764. https://doi. org/10.1590/1983-1447.2017.01.64764

31. Santos LJ, Paranhos MS. Os trabalhadores das equipes de saúde da família no Rio de Janeiro: aspectos da liderança em pesquisa de clima organizacional. Ciênc Saúde Coletiva. 2017;22(3):759-70. https://doi.org/10.1590/1413-81232017223.33112016

32. Caveiao C, Nascimento PA, Angelita V. Formação da liderança em enfermagem: revisão integrativa da literatura. Rev Eletron Estácio Saúde [Internet]. 2018 [cited 2019 Jan 03];7(1):74-80. Avaliable from: http://periodicos.estacio.br/index.php/saudesantacatarina/article/ viewFile/3866/2034

33. Evangelista SC, Machado LDS, Tamboril ACR, Moreira MRC, Viana MCA, Machado MFAS. Percurso das ações de promoção da saúde na residência multiprofissional: análise à luz de um referencial europeu. Tempus, Actas Saúde Colet. 2016;10(4):69-82. https://doi.org/10.18569/ tempus.v11i1.2291

34. Tavares AMP, Silva AKO, Fernandes MA. Situational strategic planning and applicability to occupational health: a study with fair dealers. Rev Enferm UFPI [Internet]. 2016 [cited 2018 Apr 04] 5(3):72-75. Available from: https://pdfs.semanticscholar.org/64f8/ b8618b7b6709fc36972ebcd1bc721d512031.pdf

35. Miclos PV, Calvo MCM, Colussi CF. Avaliação do desempenho de ações e resultados em saúde na atenção básica. Rev Saúde Pública. 2017;51:86. https://doi.org/10.11606/s1518-8787.2017051006831

36. Furtado JA, Campos GWS, Oda WY, Onocko-Campos R. Planejamento e avaliação em saúde: entre antagonismo e colaboração. Cad. Saúde Pública 2018;34(7):e00087917. https://doi.org/10.1590/0102-311X00087917

37. Brehmer LCF, Ramos FRS. Experiências de integração ensino-serviço no processo de formação profissional em saúde: revisão integrativa. Rev Eletrôn Enferm. 2014;16(1):228-37. https://doi.org/doi.org/10.5216/ree.v16i1.20132 